\title{
Grensverleggend hartonderzoek in Nederland
}

Citation for published version (APA):

Jukema, J. W., van der Giessen, W. J., \& Pinto, Y. M. (2006). Grensverleggend hartonderzoek in Nederland. ICIN, Interuniversitair Cardiologisch Instituut Nederland van de Koninklijke Nederlandse Academie van Wetenschappen. https://doi.org/10.26481/spe.20060511yp

Document status and date:

Published: 11/05/2006

DOI:

10.26481/spe.20060511yp

Document Version:

Publisher's PDF, also known as Version of record

\section{Please check the document version of this publication:}

- A submitted manuscript is the version of the article upon submission and before peer-review. There can be important differences between the submitted version and the official published version of record.

People interested in the research are advised to contact the author for the final version of the publication, or visit the DOI to the publisher's website.

- The final author version and the galley proof are versions of the publication after peer review.

- The final published version features the final layout of the paper including the volume, issue and page numbers.

Link to publication

\footnotetext{
General rights rights.

- You may freely distribute the URL identifying the publication in the public portal. please follow below link for the End User Agreement:

www.umlib.nl/taverne-license

Take down policy

If you believe that this document breaches copyright please contact us at:

repository@maastrichtuniversity.nl

providing details and we will investigate your claim.
}

Copyright and moral rights for the publications made accessible in the public portal are retained by the authors and/or other copyright owners and it is a condition of accessing publications that users recognise and abide by the legal requirements associated with these

- Users may download and print one copy of any publication from the public portal for the purpose of private study or research.

- You may not further distribute the material or use it for any profit-making activity or commercial gain

If the publication is distributed under the terms of Article $25 \mathrm{fa}$ of the Dutch Copyright Act, indicated by the "Taverne" license above, 
Grensverleggend Hartonderzoelk in Nederland 


\section{Grensverleggend}

\section{Hartonderzoek in}

\section{Nederland}

INTREEREDES

uitgesproken op 11 mei 2006 ,

door

Prof. dr. J. Wouter Jukema

Prof. dr. Wim J. van der Giessen

Prof. dr. Yigal M. Pinto

\section{ICIN}

wis

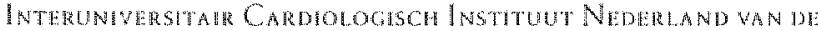

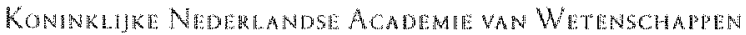





\section{Inleiding}

Op 11 mei 2006 was het een bijzondere dag voor her Interuniversitair Cardiologisch Instituut Nederland, die met recht een feestdag genoemd mocht worden voor de gehele Nederlandse Cardiologie. Drie nieuwe ICIN hoogleraren, met alle drie reeds een internationale repuratie, hielden op die dag hun inaugurele rede in de Domkerk te Urrecht.

De gebeurtenis was zeer bijzonder, maar niet unick. In 1989 vond al eerder in dezelfde gewijde ongeving een vergelijkbate ceremonie plaats, waarbij een van de huidige ICIN directeuren behoorde tot het drietal dat $z$ n intreerede uitsprak. Het was voor hem cen bijzondere ervaring bij deze nieuwe gelegenheid het driemanschap te mogen introduceren.

De expertise van de drie hoogleraren bevindt zich in de frontinie van de strijd tegen hart-en valziekten, nog steeds doodsoorzaak nummer 1 in de westerse samenleving. Mer behulp van grenswerleggend onderzoek op het rerrein van generische en regeneratieve aspecten wan hart- en vaarziekten worden nienwe onderzoek- én behandelmerhodem mogelijk. Her steunen en bevorderen van grenswerleggend onderzock is altijd het oogmerk van her ICIN geweest bij hoogleraarbenoemingen in de afgelopen 35 jaar dat dit instituut alweer bijna bestaat. 
Het ICIN is ook op andere wijze al gerume tijd bezig onderzoek naar de rol van het genoom in hart- en vatziekten re stimuleren, o.a. door het creëren wan een narionale cardiovasculaire genenbank. Het belang van een dergelijke collectie voor het cardiovasculaire onderzoek, en op remijn voor de behandeling van hart- en vaatziekten, werd door de KNAW al vroegrijdig herkend en ook gehonoreerd met een bijdrage uit het Stinuleringsfonds. Mer dank aan de directie van de KNAW gaat het driemanschap aan deze unieke genenbank in de toekconst vorm en gestalte geven.

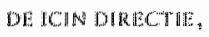

Prof. dr. C.A. Visser

Prof. dr. W.H. van Gillst 


\section{Inhoud}

Een vasculaire opknapbeurt: feit of fictie?

Prof. dr. J. Wouter Jukema

Van het hartinfarct geen moordkuil maken

Prof. dr. Wim I. van der Giessen

Een terugblik op de toekomst van het

cardiovasculair onderzoek

Prof. dr. Yigal M. Pimto 



\section{Een vasculaire opknapbeurt:}

feit of fictie?

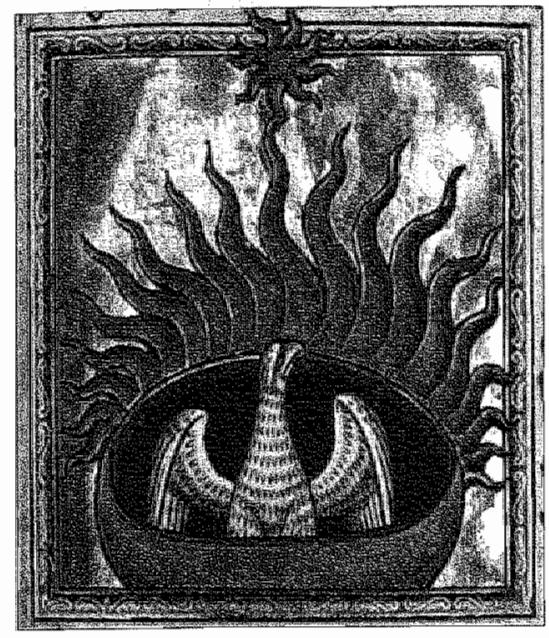

The phoenix from the Aberdeen Bestiary

REDE uitgesproken door

\section{Prof. dr. J. Wouter Jukema}

bij de aanvaarding van het ambt van hoogleraar

op het gebied van de cardiologie, in het bijzonder de cardiovasculaire regeneratieve geneeskunde aan de Universitet Leiden

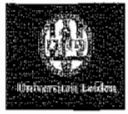


Minheer de rector Rector Magnificus, Mijnher de Decaan van de faculteit der geneeskunde Leden van de Raden van Bestuw van ICIN/KNAW en het Leids Universitair Medisch Centrum Zeer gewardeerde toehoorders,

\section{De Whoenix}

De phoenix, een mythische nuurvogel, bouwe an het eind wan zign leven voor zichzelf wen nest dat hij werwolgens ontstekt. Uit de as van het nest en de vogel verrijst een nieuwe phoenix. Die balsemt de as van de oude vogel in een ei en brengr dic naar Heliopolis, de stad wan de mmer terugkerende zon in Egypte. Volgens de overlevering kain de vogel zichzelf ook regeneren/genezen wan ziekte en verwondingen en is daamee bijna onsterfelijk. Vootal hierdoot werd her dier door de eeuwen steeds populairder bij Grieken en Roneinen en vond het zijn weg in walrijke, beroemde verhalen. Regenerarie van a angetast weefsel en van wonden, ook rond het hart, komt in meer mythische werhalen nar woren. 20 beschrijt Homerus een groot antal (cardialey werwondingen rondom de strijd om Troje in zijn 'llias'. Hec zal U niet verbazen dat vooral de wonden met en miraculeuze genezing beroemd zijn geworden. Mara is genezing wan zicke bloedvaten van het hart ook feitelijk mogelijk? Tot zeer recent dacht men van niet.

De titel wan mijn oratie luidt: 'Een vasculaire opknapbeurt: teit of fictie?' Mij is de leetopdrach gegeven werkzaam te zijn op her vakgebied van de regeneratieve cardiovasculaire geneeskunde. Regenetatieve geneeskunde houdt zich bezig met he verwangen of tepareren wa beschadigde weefsels. Dit jonge vakgebied is ontsan doo re. cente sucessen in de farmacotherapie en technologie. Wat vroeger onbehandelbar was heef nú rherapeutische perspectiowen met alle consequenties wan dien woor patienten en zorgverleners. Herover wil 
ik graag met $U$ van gedachten wisselen, watbij its mij omwille wa de nijd niee bezighoud met regeneratic wan de harspier, mar mij woon rich op het opknappen wan de bloedwaten van het hart de vasculare opknapbenr. Daarbij wil $\mathrm{k}$ onderscheid maken russen feur an Gerie. ussen reate en owerspannen verwachtingev.

\section{Coronaire atherosclerose}

Her voomaanste proces wan ziekte in de bloedvaten wan her hart is dichtstibbing of wel "coronare atherosclerose". Aherosclerose is een ziekte van de arteriele intima (de binnenbekleding van bloedwaten) die leidt rot placues (dichtslibbing) en werwolgens rot wemauwing van het lumen wan her bloedvat. Deze plaques kunnen acuut scheuren met als gevolg stolselvorming op vrijkomende atheroom, hetgeen er weer toe kan leiden dat het bloedvat geheel a fgesloten rakt. Het hartspierweetsel hierachter krijgr wervolgens onvoldoende bloed en stert geheel of gedeetrelijk af: her hartinfarct. Aan een hartinfarct kan men direct owerlijden, maar ook latere gevolgen, zoals hartalen en late hartritmestoornissen, leiden wak tot complicaries en vormen samen de belangrijkste oorzaak van mortaliteit en morbiditeit in de Westerse wereld.

Atherosclerose bestaat uir een aancal componenten en interacties die nog niet volledig ontrafeld zijn. In zijn algemeenheid is het cen langzatam progressief ziektebeeld dat al begint gedurende de kinderleeftijd. Bij sommigen is het snel progressief en wordt het al manifest in de derde levensdecade, bij anderen worde her pas veel later of zelfs helemaal nooit bedreigend. De beste manier on op bevolkingsniveau atherosclerose te bestrijden is het terugdringen van risicofactoren zoals roken, overgewichr, suikerzicke, hoge blocd druk en aen te hoog cholesterolgehalte. Wanner dit individucel onvoldoende soelas bied is valk een bypassoperatie of een percutanc coronaire intorven:tie-de "dotterbehandeling" - noodzakelijk om de wernauwde bloedvatsegmenten respectievelijk te omzeilen of te verwijden. Eerst nom 
Wh w mee natar de mogenkheid onmogelikheid tot genezing wan atherosclerose-regenerane van de bloedwawand en vervolgens natar wat mins inziens daartoe de belangrijkste geredschappen zijn.

\section{Herstel/regresste wan coronaite atherosclerose: feit of fictie?}

Toen ik geneeskunde staderde gold coronaire ar herosclerose nog als en chronisch progressieve ziekte en werd als zodanig dan ook beschreven in her Leerbok der Cardiologie. Voor deze ziekte was eigenlijk geen behandeling worhanden en watherstel behoorde zeker tor her rijk der fabelen. Overigens kunnen we hieruit concluderen dat ook makers van leerboeken hun lireratur soms nier goed bijhielden of selectief beschreven. Immers, Proudfit en Bruschke beschreven al in 1978 in een "natural history" studie wan 601 cases dat regressie, dus vermindering van de hoeveelheid arherosclerose, wel degelijk tor de mogelijkheden behoort, hoewel zij erbij aantekenden dar regressie wan atheroscletose op de ene plats frequent samenging met progressie op een andere plaars in de coronaire watboom. Er leek dus geen sprake van slechts enchionisch pragressief, mat wan een dynamisch proces net herstel ofwel regressie tegenover progressie, mer als netro urtkonst in her agemeen progressie wan ziekte.

Het hoe en warom was destijds grotendeels onverklaard, echter inmiddels worden ziektenechanismen duidelijker. Her concept dat sinds midden jaren " 80 wan ce vorige ceuw een steeds belangrijkere rol speelt, is dat de binenbekleding van de bloedvaten - het 'endotheel' - geen inerte ondoordringbare tapijtaag is, die eens beschadigd alleen maar verder kan slijten. Nee, het flinterdunnte endotheellaagje

voert de regie over een groot aantal processen in de varwand die van essentied belang zun voo bet functioneren wan her organisme. Pas als dcze actief reguterende en beschermende endotheelfunctie het laar afweren doordat er chronische ontstekng is ontstan, bijwoobceld door roken en een te hoog cholesterol of diaberes, krijgt arheroscletose zijn kans. 
Het doorgronden van deze processen en her vervolgens betandelen van ongewenste ffecten in combinatie net her stimuleren wan juist gewenste processen, bied mogeligheden ror herstel van da vartwand. Tot 20 jaar geleden waren deze mogelikheden nawwelijks worhanden, mat in de negentiger jaren ontstond er en dow braak, waaran ik ook een steenrje mocht bijdragen. Mee de ontdekking wan modeme cholesterolverlagers, de HMG-CoA reductase remmers, berer bekend als de "starines", was al ervaring opgedaan bij mensen met fumiliare hypercholesterolemie. Bij behandelde patenten zakte het cholesterol wak fraai, maar er was vrijwel nets bekend rond urkomsten op de vatwand en het optreden van myocardinfarcten bij hartpatienten. De geneesmiddelen bleven een 'nicheproducr' woor relarief zeldzame aandoeningen. Uiteindelijk durfden onderzoekers her, samen met de farmaceutische industrie, an om grote, dure prospecticve angiografische en klinische infarctstudies op te zerten, warbij patienten werden gerandomiseerd naar een 'statine' of een placebo. Nederland heelt bij deze onderzoeken een vooraanstaande rol gespeeld, vooral mer de angiografische studies MAAS en REGRESS. Noor mij was het REGRESS-project, verricht onder auspicièn van het Inrerumiversitain Cardiologisch Instituut Nederland, ICIN -.- nu een KNAW-instituut - een zeer arbeidsintensieve droommogelijkheid mijn onderzoekscarrière uit te bouwen.

De resultaten van deze onderzoeken waren spectaculair. Nú zagen we voor het eerst dat we nier alleen de progressie van atherosclerose door een enkel cholesterolverlagend geneesmidel significant konden vertragen, maar zelfs dat binnen wee jaar na start wan de behandeling er al minder hartinfarcten optraden in de behandelce groep ten opziche van de placebogroep! En dat ook nog met een geneesmiddel dac de meeste mensen uitzonderlijk goed verdragen. Dat was mog eens wat anders dan een dieet bestande uit hood, gras en een slok water! Zo begon de onstuitbare opmars van de "statines". Er was echter een 'maar'. De nam REGRESS is een acronim voor REgression GRowth 
Evaluation Statin Study. Natrad er wel over alle paventen gemiddeld een wermuderde progressie van atherosclerose op in de met pravastathe behandelde grop, matr wan en nero rot staan brengen van de zickte of de zo vurig gewenste regressie was nog geen sprake. Toch waren er hoopullo obserwates in subgroepen; het anant pationten dat allen regressie van ziekte let zien zonder progressie wan ziekte elders in de vaaboom, steeg van $2 \%$ naar $10 \%$. Het kon dus well Het perspecher wan verstekte regeneratie mer statines was geboren. Inmiddels is her dudelijk dat voor secundaire preventie - dat wil zeggen voor hoogrisico patienten die al manfestaties hebben van hart- en varzickten - in een fors antal gevallen de met standaardmedicarie bereikte $30 \%$ daling van het slechte $\mathbb{L}$ DL-cholesterol, niet genoeg is. We blijen dan immers zitren met een gemiddeld verminderde, maar wel doorgande progressie en een restrisico op niewwe hartinfarcten van rond de $70 \%$.

Is woor deze 2 wardere pariëntengroep een nog werdere verlaging van het cholesterol dan beter? Recente studies, zoals de Treat to New Targets en PROVE IT studies, laten zien dat voor de hoogrisico parient het cholesteroldoel vaak lager moet liggen. Dat is nu vastgelegd in de nieuwe CBO risicoconsensus, waraan ik ook mocht meewerken. De fraaie REVERSAL en ASTEROID studies lieten bij een cholesteroldaling van $50 \%$ gemiddeld een complete progressie arrest wan atherosclerose zien. Zon forse daling is momenteel alleen haabaar met de krachugste statines en met combinatietherapie. En dan bereiken we gemiddeld alleen nog maar cen progressie srop. Voor gemiddeld eche regressie moet het slechte LDL cholesterol misschien nog verder omlang, of moeten we juist het 'reverse cholesterol transport' aanjagen - de omgekerde cholesterol route wanuit de vatwand naar de lever -w wer zogenaande goede HDL cholesterol. Tor voor kort was dit ficvic, mar nieuw onderzock in generisch gemanipuleerde muzen en in mensen, met bijoorbeeld rorcerapib en andere HDL-cholesterol verhogende middeten, lat zien dat dir misschen ook fent kan worden. 
Van de gemiddelde naar de individnele partënt

Gemiddeld is er dus vedal nog immer progressie van coronaine atheroscterose onder statine monotherapie, Zoals angegeven geld: dit nier voor alle patienten in de studies. Hoe kunnen we de andividude patient dan beter behandelen? Het anwoord voor de tegeneratieve cardiovasculaire geneeskunde lige mijns inziens in de moleculaire geneeskunde samen met translationeel onderzoek gecombineerd met geavanceerde meetrechmieken, in het bijzonder de beeldvorming. Voor effectieve toepassing en evaluatie wan combinaties van deze niewwe parhofysiologische valwandconcepten en therapieen is een multdisciplinaire en 'from bench to bedside' geintegreerde-dus translationele-benadering een eerste vereiste. Ik licht dat in vogelvlucht toe.

\section{Moleculaire Cardiologie}

Door de neuwste ontwikkelingen in de moleculaire cardiologie - waaronder genomics - groeien de mogelijkheden van diagnostiek en het opstellen wan risicoproficlen. Dat dit reeel is hebben wij angetoond met een aantal publicaries ut ondermeer de REGRESS, GENDER en PROSPER studies. Om dergelijke ontwikkelingen te kumen realiseren, is wel eer antal zaken nodig. Bijworbeeld stimulering wan genomics en generisch epidemiologisch en ranslationed onderzoek, gebruikmakend van grote databestanden met goed getenotyperde individuen, de zogenoemde biobanken. Ik prijs me darom gelukkig dat ik aan de wieg heb mogen staan wan verschillende grotere, prachtige biobanken. Een ananal hiervan is opgezer met steun van het ICIN, de Nederlandse Hartichting en het LUMC.

DNA-, pharmacogenomics en proteomics-onderzoek speele hierbij een grote rol. Woor analyse is in Leiden don ook een gedegen samenwerking met o a. her Sylvius en Gorlacus Labopgezer, in samknwoking mer collegae Prof. Frants, de Knifl, Wan de Greve, Hankenaier en Liem, en met de Molectare Epidemiologiegrocp wor de high throughput logistiek in sumenwerking met collegae prof. Slaghom 
en Dr Heymans. Her genoryperingsplatorm wan het Center for Medical systums Bology, de afdeling moleculaire epidemiologe en de medische statistick zin hier geintegreend voor een optimale analyse van de wak complese datasets. Voor verder onderzoek zijn inmiddels NHS grants verworwen met name ook in samenwerking met de groep van Prof. Koos Zwinderman, nu hoofd biostanistiek in her $A M C$.

Uir al dir onderzoek moet de onwhkeling van famaca op individuele maat voorvloeien: één geindividualiseerde pil voor de patient, gebaseerd op onder andere famacogenetics, met bijv. 2 of 3 farmaca indeze pil.

16. stel voor deze pl de 'individualised pill' te noemen; dat is dus vel subtieler dan de nu wel voorgestelde 'poly-pill' met maar liefs 7 verschillende farmaca, gebaseerd op de uitslagen woor de gemiddelde patient. Overigens makt dit teveel aan Carmaca deze "gemiddelde poly-pill" voorlopig ook nog "onmakabaar" en "onslikbaar". Ik begrijp ook wel dat de nam 'individualised pill' nier lekker "bekr", dus her zall dan wel "indi-pill" worden. Voor de racecircuitkenners onder u klink die naam lekker sportief en deze kleinere pil glijdr vast razendsnel doot het strotienhoofd.

\section{Translationeel onderzoek}

In "ranslationeel onderzoek" werken klinische en niet-klinische onderzoeksgroepen samen. Resultaten van basaal onderzoek vinden zo hun weg naar prakcische toepassing. Dar dit geen fictie is maar feit met mooie resultaten blijkt uit onze situatie in Leiden, waar al vele jaren een geïntegreerde Leiden Vascular Medicine groep operationeel is, alsmede themagroepen zoals Regeneratieve Geneeskunde en Vasculaite Geneeskunde. Onder andere op de afdeling cardiologie heeft een en ander geresulteerd in een operationeel wetenschappelijk onderzocksysterm.

De loopbrug tussen het splinternieuwe onderzoksgebouw en her LUMC-gebouw is behalve erg handig ook en mooi symbool voor de 
brug tussen prekliniek en klinick. Ook TNO on LUMC weren elkar. te winden. De strategische alliantie tussen beiden wit zith onder andere in bet breed gedragen 'atherosclerose' overleg in sameawerking mat Prof. Havekes en Dr Quax. Zo ontdekten we in het multicenter translationale GEnetic DEterminants of Restenosis (GENDER) project dat de onstekingsbevorderende stof Tumor Necrosis Factor- $\alpha$ an betangrijke oorzak is wan vervauwing wan de kransslagader, nadat deze is 'gedottend".

Soortgelijk geïntegreerd preklinisch-klinisch onderzoek verrichten we inmiddels ook met betrekking op het HDL cholesterol en "reverse cholesterol transport in samenwerking met Dr Rensen.

\section{Implementatie}

Implementatie van al anwezige kemis in de dagelijke prakijk is een belangrijk aandachtspunt. Ook andere disciphnes zoals proteomica en immunologie spelen een rol bij de verdere onwikkeling van basale kennis over de processen die leiden tot hart-en vaaziekten. Kortom: optimale regeneratie van ziek weefsel is geen sinecure. $0 \mathrm{~m}$ wan fictic naar feit te komen moet aan veel voorwarden tegelikertijd voldaan worden. Ik zou dit in analogie met Jared Diamond in zijn boek 'Guns, germs and steel, the tate of human societies' het "Anna Karenina principe willen noemen, naar de beroemde openingszin van Tolstoj's gelijknamige boek, die luidt: Gelukkigge gezimen zijn allemaal hetzelfde; ieder ongelukkig gezin is ongeluklig op zijn eigen manier.

Een gelukkig huwelijk moet in een groot aandal opzichten slagen. Zir hot met én van de wezenlijke, aspecten niet goed, dan kan dat een huwclik de nek ondraten, ook als her an alle andere woorwatrden voor geluk wél voldoet. Dit principe is, mutatis murandis, ook van toepassing op de regeneraneve geneeskunde. Crote stappen vooruit zijn per defnitie riskan, ondat je wellicht aan efon mextere worwarden niet woldoet. Dit hebben we gezien bij de regeneratieve gen- 
therapie in en Amerikans zickenhus, warbif een parient vroegritdig strert. Hierdoor werd gentherapie en enorm eind reruggeworpen. Resper roor wagstukken is essentieel in de gereskunde. Zoals cen Inut-sjamaan oon zei tegen een poolonderzoeker Wij vrezen de koude en de dingen die we net begripen. Maar het meest vrezen wij de daden van de zorgelozen in ons midden'.

Alle eerder genoemde kennisaspecten zijn essentied voor de ontwikkeling van nicuwe strategiedn voor preventic en therapie. Voor een optimale implementatie moeten we dus volgens her "Anna Karenina principe" aan een annal voorwarden goed en tegelijkertijd voldoen. Dit zijn mins inziens:

1. Integratie van klinisch en prektinisch, dus transtarioneel onderzoek.

2. Goede verzamelingen van parientenpopulaties-biobanken.

3. Projectmatige samenwerkingverbanden. I $k$ nomde al een aanal suclies, maar ook onze cardiale MISSION" - en Diabetes Cardiovascular Risk Management DIACARM, PROSPER en ICD-2 projecren zijn goede woorbeelden.

4. Geawanceede meettechnieken, in het bijzonder de cardiale imaging.

5. Goede klinische trials, wan fase 1 onderzoek tot fase 4 , samen met andere, al dan niet industriale, parners.

6. Lasi but not least: goede data integratie en analyse

\section{Dames en heren,}

Aan het einde gekomen wan mijn rede, spreek ik gaame nog enige dankwoorden uit.

$1 \mathrm{k}$ dank her College van Bestur wan de Universiteit Leiden, de leden van de Raden van Bestumr wan het Leids Universitar Medisch Cenrum, het Interminersitair Cardiologisch Institut Nederland en de Koninklijke Noderlandse Akademie woor Wetenschappen allen die an de totstandkoming van mijn benoeming hebben bijgedragen, voor het in mij gesteldio wertroumen. 
Her ICN en in her bijzonder de hudige directe bestande wo de hooggelearden Cees Wisser en Wiek wan Gilst samen met hun voongm. gers en Mama Helmers voor het wele jaren in mij gestelde vertrowwen. Her is voor mij een genoegen hier te mogen statn samen met collegae. Van der Giessen en Pinto. In deze context dank ik ook mijn angiogra fische leemeester de hooggeleerde Abert Bruschke, de mij als jonge onderzocker durfde te parachuteren in een groot onderzoek dat in zwar weer verkeerde.

Hooggeleerden van der Wall, Schali en Bax, beste Emst, Martin en Jeroen. Dank voor jullie inspiratie, humor, en de geboden kansen. Ik wardeer het enorm dat nieuwe ideetn op onze afdeling rum baan krijgen. Ih zie uit natr onze verdere intensieve samenwerking.

Hooggeleerden Rabelink, Romin, Rosendaal en Fibbe, beste Ton, Hans. Frits en Wim, dank woor de zeer pretrige samenwerking en het perspectief in de mieuwe thema"groepen "regeneratieve en wasculaire geneeskunde".

Beste collegae uit de kliniek en mer name ook wir de prekliniek, in het bijzonder de hooggeleerden Havekes, Biessen, Westendorp, wan Burkel, Slagboom, de Knifff. Frants en van Zonreveld en de zeergeleerden Quax, Rensen, Smit, Pereira, Princen, Heymans en Liem, en alle andere die ik hier helaas niet met name kan noemen, samenwerking med jullie kan nief genoeg gewaardeerd worden.

Waarde collegae wan de afdeling cardiologie, verpleegkundigen, met name Els, Ineke, Trube en jullie teams, pronovendi, studenten, secrearivat en computergroep, het is een genoegen om elke dag met zo"n geoliede machine vol gemorweerde medewerkers ne mogen werken.

Hooggeleerde Kasteden beste John, jij hebr mij zo'n 15 jaar geleden 
gewezen op her belang van goede biobanken, dat was toen revolutionair. Dat heeft geleid tor vele gezamenlike wetenschappelijke publicaties en evenzoved vriendschappelijke momenten. Laten we zo doorgan!

Hooggelcerde Zwinderman, beste Koos, we leerden elkatr kennen op het station Lelylan, wat we ons samen opwonden over de zovedste trenvertraging. Spoedig bleck dit niet onze enige overeenkomst. Her kikte zo goed dar je de 'huisstatisricus' werd wan het RECRESS ondreroek. Je vertrek uir Leiden betreurde ik dan ook zeer, hoe prettig mijn relatie met de Medische Statistiek in Leiden nog is. Ondat weel van min onderzoek multi-center is kon je gelukkig een belangrijk deel van onze gezamenlijke databestanden bliven beheren en analyseren met uitstekende gewolgen. Bovendien hopen de Jukema's dar onze wriendschap met jou en Bernadette, alsmede onze fameuze "theebezoekjes" lang zullen blijen bestaan!

Op mijn eigen familie en schoonfamilie is het gesladagde Anna Karenna principe zeker van toepassing en ik ben hier zeer gelukkig mee.

Mijn vader kan hier vandatag helaas niet meer zijn, evenmin als op mijn promotic nu alweer 10 jaar geleden. Het openingscitat van mijn proefschrift afkomstig uir de Odyssee, waruit hij mij zo valk vertelde, is zeker op hem wan toepassing.

Her moer hem een genoegen zijn dat ik hier sta, in toga op een kansel. Mojn nieuwe toga gaa straks in zim oudk togakoffertje.

Ma: jouw liefdevolle opvoeding had én specifiek kenmerk: er moch veet als we her maar helemal licen kloppen, organisatie als eerste vercisce. Van de leerschool hebben wij alleman nog steeds weel plezier!

Mijnzussen: Olga altijd mijn artistieke leidsw rouw en rots in de branding. en Hawn: als kleine kinderen bleven we samen in her zickenhuts, howel een van ons al berer was, dar zegt genoeg. 
Gerrolt: brother in arms, er zijn vast meer broers die cen surfplank delen, maar dat we ook samen én surfpak deelden getuigr wan een bijzonder warme band, hoewel de pakwissel juist waak een konde aangelegenheid was.

Onze kinderen: Jelmer, Ruwrt en Marlide, cen vrolijk superream! Onze bootvakantie in Frankrijk: samen sturen over kronkelige en rotsige rivieren en 100 sluizen op klauteren, bedienen en passeren. Teamwerk on nooit te vergeten.

Lieve Swanette: Her is vandaag een bijzondere dag, namelijk... onze trouwdag. Heliopolis, de zonnestad war de phoenix zijn toevlucht zocht moet toch fictie zijn, want voor mij is het cen vaststaand feit dat de heerlijke zonnestad nier in Egypte ligr, maar bij ons thuis, dankzij jou.

Ik heb gezegd. 


\section{Referenties:}

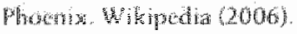

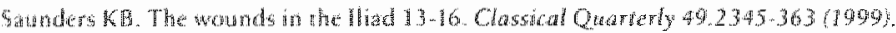

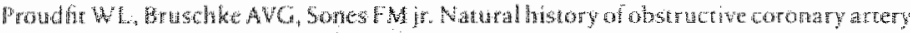

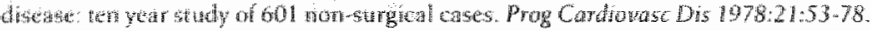

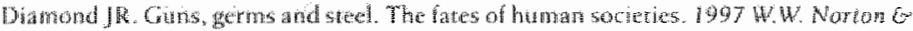

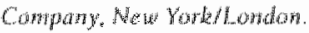

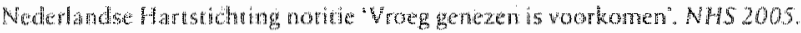

Jukma JW, Brtschke AWG, Reber JHC. Progression and regression of cononary athe

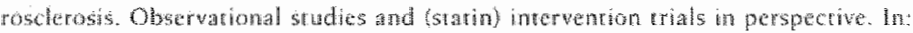

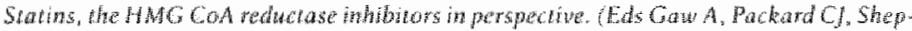

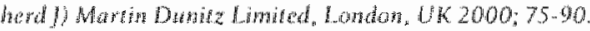

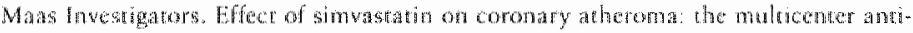
atheromat sidy (MAAS) Lancet 1994;344:633-638.

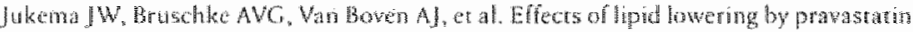
an progresion and regression of coronaty anery disease in symptomatio men wh nor-

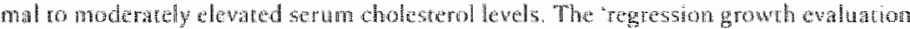
statin stuly' (RECRESS) Ciratomion 1995,9:2528-40.

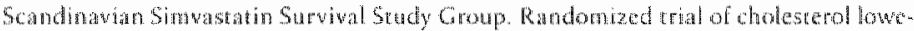

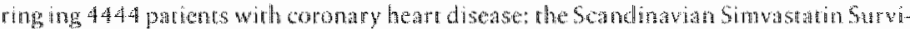

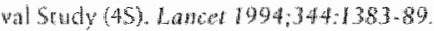

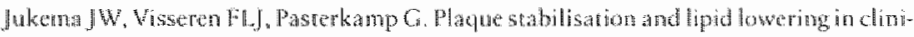

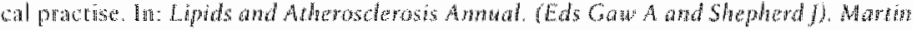
Duritz Lmited. Landon, UK 2007, $95-130$.

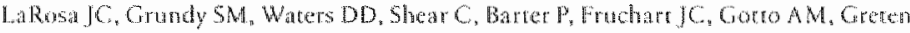

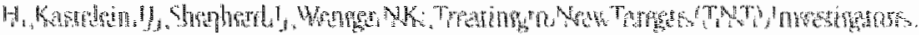

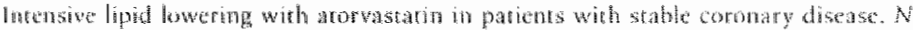
Lingt Mid. $200 \%, 852: 1425.35$.

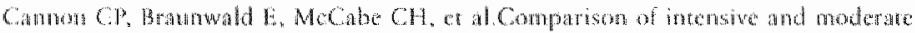

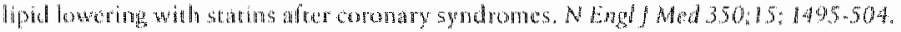

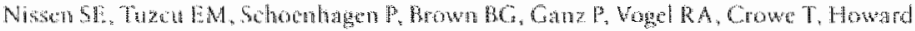




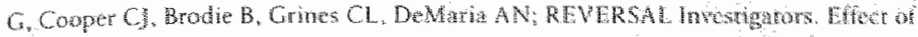

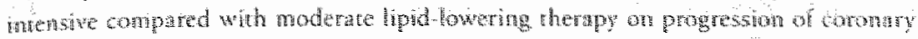

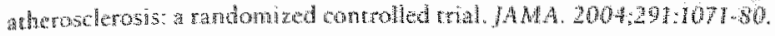

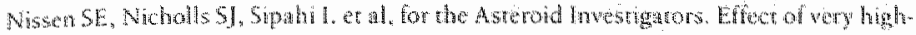

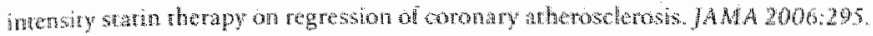

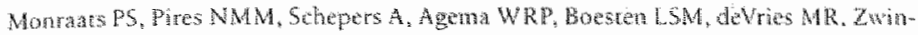

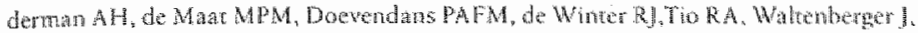

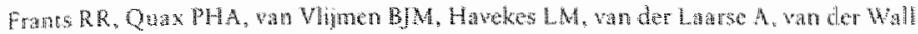

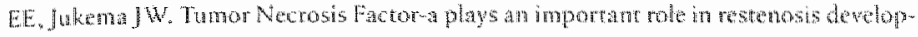
menr. FAEB Joural 2005:19:1998-2004.

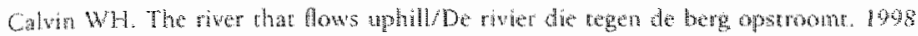
ooverampromethus, Anstevam.

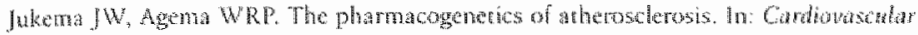

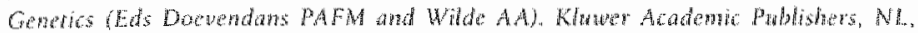
$2001 ; 83.100$.

Homeros.

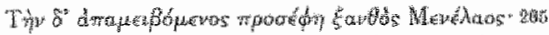

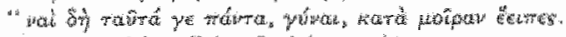

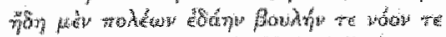

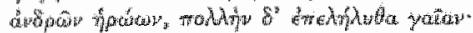

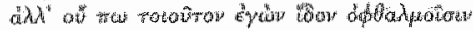

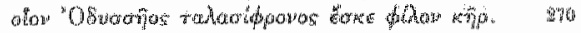

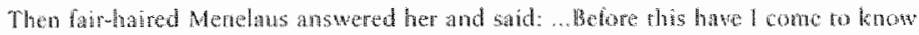

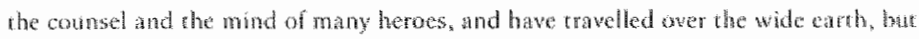

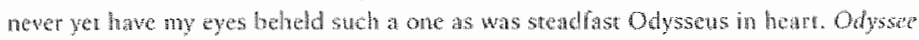
4. 265.270 



\section{Van het hartinfarct geen moordkuil maken}

REDE uitgesproken door

\section{Prof. dr. Wim J. van der Giessen}

bij de aanvaarding van het ambt van hoogleraar 'Pathofysiologie van acute coronaire syndromen" aan de Erasmus Universiteit Rotterdam. 
Minne Heren Rectores Magnifici, leden van de Colleges van Bestuur van de Universiteiten van Utrecht, Leiden, Maastricht en Rotterdam, Leden van het Bestuur en de Wetenschappelijke Raad van het Interuniversitair Cardiologisch Instituut Nederland en van de Koninklijke Nederlandse Akademie voor Wetenschappen, Hooggeleerden, Zeer gewaardeerde toehoorders.

Op een plaats als deze word je wel gedwongen om even stil te staan bij de geschiedenis. U hebr allemaa! bij het binnengaan van de Domkerk kunnen zien dat deze vanaf 1254 gebouwd is als de Si. Maarten kerk. De Engelse schrijver Geoffrey Chaucer gaf een treffende beschrijwing van de arts uir die rijd in zijn Canterbury Tales. Die arts was zeer kundig, kennende alle ziekten, of ze nu veroorzaakt werden door hitte, koude, vochtigheid of droogtet. Echter, daarnaast gaf Chaucer als minder positieve eigenschap aan, dat tijdens de artsenstudie weing rijd aan onderricht in de theologie werd besteed. In de huidige artsenstudic komt theologie helemaal nier meer ter sprake, maar de paradox is dat in deze tijd van afnemend kerkbezoek her optreden van juist drie artsen zorgt woor een volle Domkerk.

\section{Het thartinfarct}

Het hartinfaret wordt gedefinieerd als cen aanval van pin op de borst, die minstens 30 minuten a anhoude, en waarbij na enige uren hartspecifieke ewitfragmenten in the bloed angeroond kunnen worden, als bewijs dar schade is opgerreden ${ }^{x}$. De mate wan verandering van het clectrocardiogram brengt verder een onderverde- 
Whing an in het rype hartintaret. Deze defmitie geldt overigens pas een par jaar. Een substantieel deel van de infarcten die we nu diagnostiseren, zouden tot enkele jaren geleden onopgemerk zijn geblewen. Het onderzoek nar in her bloed rijkomende tactoren heeft zeer veel bijgedragen aan het nawkeuriger maken wan de diagnose, en geef ook richring aan de inscharting wan het risico dat de patient loope in de eerste periode na het infarct. Dit risico op een re-intarce of overlijden in her eerste jar kan wel oplopen van $1 \%$ to bijna $30 \%$ bij die patiënten die onder de oude definitie geen infarct gethad zouden hebben".

We hebben het hier dus over een levensbedreigende aandoening. Meer dan 40\% van de Nedenlandse bevolking overtide door hart- en watzickten, al 50 jaar doodsoorzaak nummer én". Van de wolwassenen zoals vamiddag in deze kerk verzameld kun je verwachten dat minstens de helft zal overtijden an hart- on valziekten.

Vanmiddag wil ik een viertal aspecten van her hartinfarct en hat behandeling met u bespreken. Voor degenen onder u die geen hartinfarct in de omgeving hebben meegemakt, of dic er geen professionele kennis van hebben, zegt een woobeeld warschiplijk meer dan een lang betoog. Daarom volg hier een korte, overigens gefingeerde ziektegeschiedenis:

Het betreft een man van 59 jaar. Y., werkend bij een beveligingsbedrijf en nooit een probleem met zijn gezondheid gehad. Zijn vrouw drong er al enige maanden op aan te stoppen met roken, hem er aan herimerend dat zijn vader op 60-jarige leeftijd plots vidensen wakantie was overleden.

's Margens on 6 wur werd $Y$ wakker met ping in zijn borst. Hif draaide zich eerst op zijn andere zij, mat de pinn werd snet erger. Y ging naar de ketaken om een glas melk te drinken wot hij wel vaker deed, mar deze keer hielp het niet. Hij begon te 
tanspheren, wolde zich slap en moest gaw zituen. Zo wof zin wrow hem om 7 wh and blek en transpiremd. On 07.15 wh was de gealameerde huisarts ter platse. Y vertelde wat er was

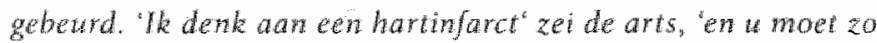
snel mogelijk nat het ziekenhus: Ze belde om een ambulance. In de twintig minuten tot de ambulance werscheen, nam ze nog zijn bioeddruk op en schreef een briefje woor de specialist. De ambulance verscheen en toen was her ineens druk. Een hartfim werd genaakt die de diagnose bevestigde: 'Waarschinlijk groot harinfarct. "Reperfusie-therapie geindiceerd", stond er op de re. gistratie.

Ondertweg raat het ziekenhuis wet Y Y hartritne toenemend onregelmatig. Tot tweemal toe moest een electroshock hem weer bijbrengen.

On 8 un reden de ambulanceverpleegkundigen de brancard de harkatheterisatiekamer binnen. In de wachtruimte kreeg zin vrow koffie en belde zij de kinderen.

Om 9 un mocht ze bij Y op de intensive care. Een zoon was inmiddels bij haar. $Y$ zag er niet zo graw meer uit, en de plin was nog niek weg, maar gelukkig al een stuk minder. "In de laop van de dag weten we of de beschadiging wan wh hart meevalt' zei iemand in en witte jas die zich juist als dokter had voorgesteld. 'Het afgesloten bloedvat is weer goed open en whebt wee stents gekregen?

Vier aspecten wan dit geval wil ik verder mer u bespreken:

\section{Snelue en effectieve reperfusietherapie}

Ten ecrste is het zo snel mogeligk openen wan het afgesloten kransvat bij een hartinfarct wan levensbelang. Onderzoek van onder andere Boersma in Rotrerdam heeft haten zien dat de én- 
mands-sterte bij een interventie binnen de 3 uur 6 is 7 be dragat. Boven de 6 un loopt dit al op naar 100 . Een goede woe gankelijkheid en organisatie van de zorg rondom het hartarct is dus belangrijk. Een recente rapportage van een commissie van de Gezondheidsrand lat zien dat na alamering wan huisarts of telew foonnummer " 112 ' $90 \%$ wan de Nederlandse berolking binnen 60 minuren, en $95 \%$ binnen 90 minuten een centrum mer mogeligkteden tot kranswatinterventie kan bereiken. Her valt misschien nog enige tijdwinst te boeken, mar warschinhilker is dat de meeste tid verloten gat tussen het ontstan van de klachten en de hulpvraag.

Onze casus is een gunstig woobeeld. Binnen 2 ur na ontstan van de klachen is de patient in het ziekenhwis. Gemiddeld voor Nederland is ongeveer dric war.

Preventieprogrammas gericht op voorlichting over symprow men zouden hier veel levens kumen redden. Geschat word dat mar $50 \%$ van de acure infarcten nu volgens de modernste inzichten behandeld worden. Het Euro Surwey onderzock lat zien dac vooral ouderen boven. 70 jar en vrouwer zich laat of niet melden en daardoor niet de optimale behandeling krijgen ${ }^{f_{2}}$. Binnen het ziekenhuis zou ook winst te behalen zijn bij een 24 uurs paratheid van een spoedkamer inclusief personeel en het direct overbrengen van de patiën vanuit de ambulance naar deze laciliteit. Een dergelijke dedicated faciliteit is kosteneffectief te exploiteren. Een ruwe schatting van 8.000 mal een uur tijdwinst en $2 \%$ vermindering van sterfe levert 160 minder doden per jaar op. Als we datmast nog eens extra 4.00070 -plussers rijdig kunnen behandelen mer gemakkelijk $5 \%$ vermindering van sterfe levert dat nog eens 200 minder doden op. 


\section{Behandeling van de watwernawwing en la ane termijn oplassing}

\section{door toepassing van medicinale stents}

Een tweede belargrijke appec is de effectivicen van het open maken en open houden wan her afgesloten kranswat. Onderzoek wan voral de groep wit Zwolle law zien dat een dot terbehandeling effectiver is in her openen wan het bloedvat dan stolseloplossende medicinen. Het gebruik van stents houdt hierbij de vaten beter en langer open dan de ballon alleen ${ }^{2}$. Nieuwe stents die medicinen op tun oppervlak hebben die geleidelijk worden afgegeven, ofwel medicinale stents, zijn herbij en verdere verbetering. Lemos wan onzegroep toonde aan dat het gebruk van deze stents bij patienten mer een hartinfarce her percentage cardiale gebeurtenissen na 10 maanden nerugbracht wan 17 naar $9 \%$. Deze vermindering werd vrijwel uirshitend beteikt doordat medicinale stents het bloedwat beter open houden dan niet-medicinale stents. Hofma toonde aan chat het in dit verband nier uimaakt welk wan de huidig beschikbare medicinale stents gebruikt wordt". Deze eerste generarie medicinale stunts bestaat uit een metalen stent, watop een coating is angebracht die de medichnen bevat. Met Heleen van Beusekom konden we recent aantonen dat deze coatings met medicinen een lokale reactie uitlokken die het herstel van de vatwand aanzienlijk vertragen ${ }^{10}$. Dit is waarschijnlijk de reden dat er nog steeds, zij her in mindere mate hervernawing ter platse optreed en dat in een klein percentage plorse trombosevorming vórkomt. Diverse laboratoria, waaronder het onze, zijn nu bezig om de coating te verbeteren en minder agressieve medicinen toe te passen. Het valt te verwachten dat op niet al te lange termiju een tweede generationcdicinale stents beschikbar komt met oprimale resultaten, zodar de kransvaten permanent open gehouden kunnen worden. De werzuchting van Serruys in zijn orate nu bija 17 jar geleden dat dit bemoeilijk word door te geringe samenwetking russen farmacenische on stentindustrie lijk nu niet meer van tocpassing. 
Er is nmiddels intensief samenwerking tussen academsche centra en deze industrieen die een positieve toekomswerwachting rechtvardigen.

Or de heer $Y$ wit onze casus zo"n medicinale stent breeg. wayneldt het werhal niet. Gemeren mar he landelik gemiddelde is de kans hierop miet groot. Slechts in enkele centra worden deze stents als rowhine gebrukt. De belangrijkste belemmering voor een mime. re toepassing is het fet dat medicmale stents niet in ons vergoedingensysteen zinn opgenomen. Wij lopen hierbij ver acher op landen als Zuitsenand, Verenigde Staten on zels Portugal.

\section{Beperking wan ischemische schade}

Het derde aspect na het herstellen wan de bloedroevoer is de beperking wan de groote wan her infarct Infarctgroote is een bepalende factor woor de kans op complicaties en sterfe na her infaret. Daarom zijn matregelen die de infarctgrootce kunnen beperken zeer gewenst. In diermodellen bleken diverse geneesmiddelen effectief. Voorbeelden zijn onder andere remmers of blokkers van vije zuurstoradicalen, onstekingsfactoren of ontstekingscellen, stabilisaroren of antagonisten wan ionenkanalen in de wanden van de hartspiercel, substraten voor en transportactoren van energierike verbindingen etc. Deze middelen zijn echter vitsluitend eltectief wanneer ze toegepast werden vón de atshluing van het kransvat. Bij parienten mer een acuut hartimfarct is die mogelijkheid wooraf medicijnen toe te dienen niet anowezig, en in pariënrenstudies bleken geen van deze middelen dan ook overtuigend effectief. Een tor nu tok praktisch toepasbare matregel die ook bij patienten de infarctgroote lijkt te beperken, is het bij hethaling kordurend afshiten en weer openen van het kranswar met exn ballonkathetet direct na de reperfusie, ook wel postconditionering genoemd. Een eerste studie uit Lyon liet bij cen 15 -al patienten een reductic van 
de infarctgrootte 2 en van meet dan $30 \%$. In die studie werd echter cen net erg nauwkewrige matat wor infarctgrootre gebrukt". Ook werden de pattenten slechen kon vervolgd. Otiver Manintveld en Dirk Duncker van Experimentele Cardiologie toonden postconditonering ook bij de rar an. Reductie van de infarctgrootte van 25 tot 40 procent bleek ehter afhankelik van de duur van de at sturting. Aleen bij langere infarctuur werd een gunstig effect gezien. Het mechanisme likt te berusten op het anzetten van een signaal in het hare dat celdood reme, naast het verminderen van vrije zuurstofradicalen. Mer Olivier Maninveld, Dirk Duncker, en Wim Lagrand van de Intensive Care gaan we nu onderzoeken of we de kinische resuldaten van de Franse groep kunnen bevestigen mer meer geavancerde technieken.

\section{Herstel van de hart-en vatfunctie in de cerste periode na het infaret}

Verschillende geneesmiddelen, watronder betablokkers en remmers van het renine-angiotensine systeem verbeteren de hartfunctie en de prognose van patienten na en hartinfarct. Toch ontwikkelt cen groot aantal patienten hartaken. Ekn wan de oorzaken hievoof zou een afwijkende respons kunnen zijn van het geïlarcerde hart op sommige farmaca. Daphne Merkus van de Experimentele Cardiologie toonde bijwoorbeeld bij varkens mer een myocardintarct an, dat de respons op sommige velgebruikte bloedvatverwijdende of juist bloedvatvernauwende medicinen als endotheline anders is dan in her nomale hart". Mer Daphne bereiden we nu een klinische studie voor om dir ook bij patiènten na het hartinarct te onderzoken. We hopen met de resultaten wan dit onderzoek in staat te zijn om patienten beter in te stellen op medicijent en zo de voomuigang tor hartalen te vertragen.

De linker harkamer bevat ongeveer 4 miljard hartspicrellen. Om falen van de linker ventrikel teweeg te brengen moer door het 
hartinfarct ongeveer een kwart van die spiercellen afsterven. Met recht een moordkuil. De laatste tien jaar is er een ontwikkeling op gang gekomen om dat verlies an spiercellen te herstellen. Met het injecteren wan verschillende rypen voorlopercellen of stamcellen bleek her mogelikk om in diermodellen de linker hartkmerfuncrie te verbeteren ${ }^{13}$.

De eerste kleinere klinische studies heten ook positieve resultaten zien zoals verbeterde doorbloeding, minder litrekenweetselvorming, of zelfs verbetering in linker hartkamerfunctie De interpretatie van deze resultaten wordt echter bemoeilijkt door het ontbreken van een goede controle groep.

De volgende fase was die van de gerandomiseerde studies van beperkte omvang. Voobeelden hiervan zijn BOOST, REPAIRAMI, Leuven studie en ASTAMI.

Deze vier onderzoeken richtten zich ook op de behandeling van patienten met een acuur myocardinfarct mer stamcellen uit beenmerg. De resultaren van deze studies variëren. REPAIR-AMI lier een significante verbetering in hartunctie zien. De BOOSTrrial liet een significante werbetering zien in de eerste 4 manden, maat dit verschil verdween na 18 manden. De Leuven trial toonde geen significant verschil aan en in de ASTAMI trial word zelfseen grotere verbetering in de controle patienten wargenomen.

Deze onderzoken markeren de periode wan relatief kleme studies. Resultaren tot mu toe laten zien dat de behandeling goed uirvoerbaar is en hoewel er geen overweldigende positieve resultaten werden gezien, Hijkt de behandeling met beenmergcellen geen risico met zich nee te brengen. Om meer inzicht te krigen in thet effect van de behandeling zijn nu grotere studics nodig. Bij woorkeur moeren meerdere centra atn de studies meedoen, en moeren paticnten lang verwolgd worden.

Met steun van he lnteruniversitair Cardologisch Instimur No. derland en de Nederlandse Harstiching is recent een eerste grote 
Studie in Nederland gestarr nat het effect on beenmergstancellen wa het harinforet. Resultaten worden echter niet woor 2007 werwaht. Een belangrijk bikomend voorded van deze interuniversibare studie is dat we hiermee ook een technisch hoogstaand platform creeren om roekomstige infarcustudies te kunnen doen.

De afgelopen rijd zijn er in dagbladen negatieve berichten verschenen over stamcelonderzoek. Dit dreigt het woord stamcel te stigmatiseren in de publieke opinte. De weuenschap kan zich hier sleches regen verweren door op verantwoorde wijze door te gaan met kwalicatief hoogstaand onderzok en de resultaten hiervan op een transparante manier te communiceren. Ik ben van mening dat ook voor stamcelonderzok de stelling wan Clark geldt, dat: 'de warde van onderzoek voor de korte termijn meestal wordr overschat, maar dat haar warde voor de lange termijn nooil onderschat moet worden"

\section{Graag wilik mijn dank zeggen aan:}

De Leden van de directie en het bestuwr van het Interwiversitair Cardiologisch Institun Nederland, de Koninklike Nederlandse Akademie voor Wetenschappen en de Erasmus Universiteit Rotterdam. lk dank u voor deze benoeming en he in mij gesteld vertrowwen. U bied mij de mogelijkheid om onderzoek naar en de behandeling van acure coronaire syndromen plaatselijk en ook op lardelijk nivo te stimuleren. Daanaast wil ik mij inzetten om een permanent national platiorm voor onderzoek van acute coronaire syndromen re onderhouden.

Medewerkers van het Thoraxentrum van het Erasmus MC, en in het bijzonder van Experimentele Cardiologie en Intervevice Cardiologie. Vandag mag ik hier op de kancel staan, matr ik had dir nooit bereikt zonder jullie. Bij moeilije klinische of experimentele procedures blijkr telkens weer jullie professionaliteir. Mar als het 
werk her roelaat, moer er ook minstens één keer per dag gelachen worden.

Professoren Paul Hugenholtz, Jos Roeland, Marten Simoons, Piet Verdouw, Klaas Bom, Parrick Serruys, Piw de Feyter, jullie belichamen voor mij de cultur van her Thoraxcentrum, zoals ik dic anwakelijk als studen en later als staflid zo ben gaan warderen. Elk van jullie zijn woor een bepald aspect een woorbeeld voor me gewreest. Jullie behouden mijn respect.

Lieve moeder. Geloven in jezelf en je gezin is jouw motto. "k keb daarten wolle van geprofiteerd. Ik dank je voor alles.

Noelle. Anna en Rose. Cardiologie is weliswar belangrijk maar toch slechts een deel wan mijn leven. Her allerbelangrijkste deel zijn jullie. Dat zal ook na vandaag zo blijven. lk ben er trots op dat ik jullie man en vader mag zijn.

It heb gezegd. 


\section{Referenties:}

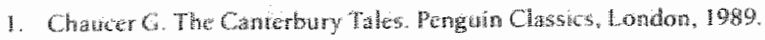

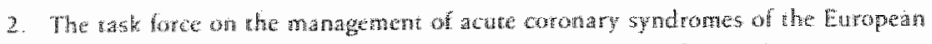

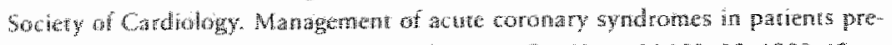

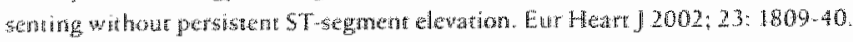

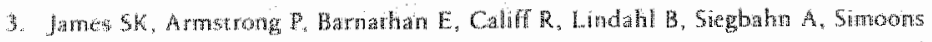

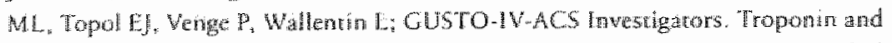

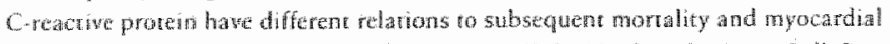

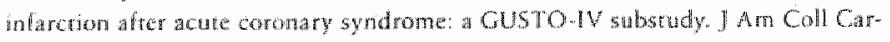
Whe $2003 ; 4: 916 \cdot 24$.

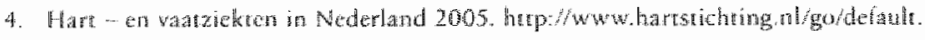
aspind

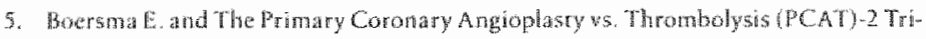

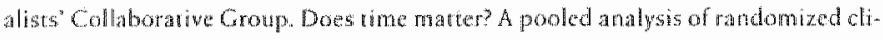

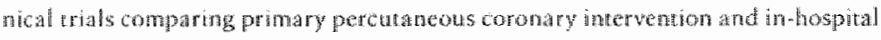

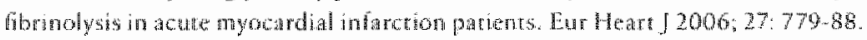

6. Rosengren A, Waltentin 1., Simoons M, Gin AK, Behar S, Bater A, Hasdai D. Age. clinical presentarion, and oucome of achte cormaty syndromes in the Euroheart

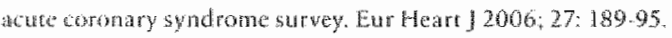

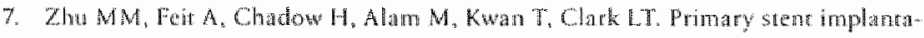

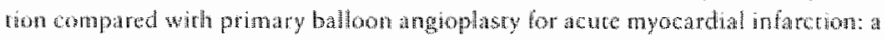
meta-analysis of randomized climical trials. Am f Cardion 2001; 88: 297-301.

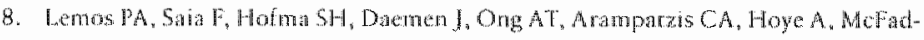
den E, Sianos $G$, Sntilts PC., wan der Gessen WI, de Feyrer Pan Domburg RT, Ser-

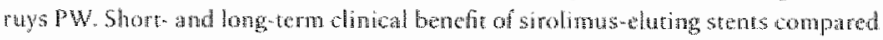
wo conventionat bare senes for pationts wh acute nyocardial infarchon. A Ara Coll Cardint $2004 ; 4,7048$.

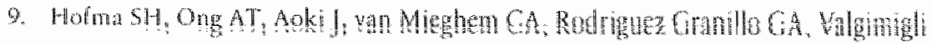

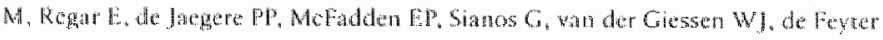

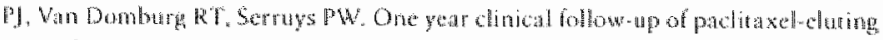

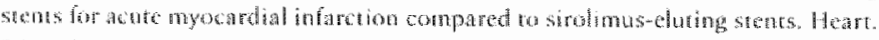
$2005,91: 1176,80$

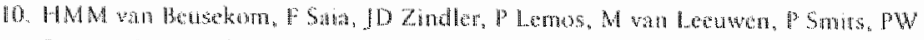

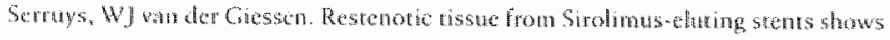




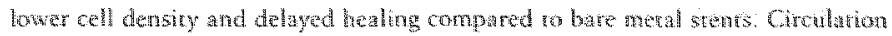
2004: $110: 111-618$.

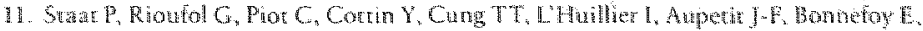

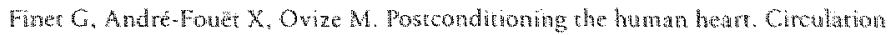
$2005 ; 112: 21,3-8$.

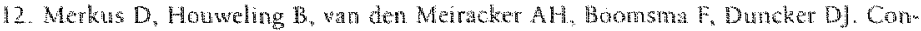
truburion of endothelin ro coronary wasmotor tone is abolished ater myocatial matarcion. An ] Physiol Heart Circ Physol. 2005, 288: 4871-80.

13. Murry CE, Renecke H, Pabon LM. Regenertion Gaps. Obserwions m stem cells and cardiac repair. I Am Coll Candiol 2006,$47 ; 177785$.

14. Chark 3 , Sranton $N$. Innovation in techology and orgamizatom. Routlodge, Now rok, 1989 



\section{Een terugblik op de toekomst van het cardiovasculair onderzoek}

REDE uitgesproken door

\section{Prof. dr. Yigal M. Pinto}

bij de a anvaarding van het ambt van hoogleraar Cardiologit, in het bijzonder moleculave aspecten van hattalen aan de Universiteit Mastricht 


\section{Rectores Magnifici, Leden van de KNAW, Decanen, Hooggeleerden, geachte aanwezigen,}

Ik ben buitengewoon vereerd on in dit illustere gezelschap minn eerste openbare les te mogen houden. Ik ben in her bijzonder vereerd dat ik die les in deze kerk, wanaf een kansel mag geven. Jukema's en Van der Giessens hoor je misschien nog wel eens wan een kansel donderen, maar ik kan u werklappen dat u niet vaak een Pinto op het preekgestoelte ziet platsnemen. Dat dit nu zo kan toont de flexibiliteit van onze cultuur. Om academische plechrig. heden en ook feesten te houden in een kerk wereist het vermogen om clat wat onwrikbaar lijkt, toch anders te bezien. Het zal de gemiddelde middeleeuwer onwarschijnlijk voorkomen dat we nu in staat zijn on in een kerk, een feestzaal te zien.

Midden jaren tachtig zocht ik als student een laboratorium on onderzoek re doen. Hans Hillige gaf me toen het advies om bij Wiek van Gilst langs te gaan, die was niet lang daarvoor gepromoveerd. Achteraf gezien is dat geen slecht idee geweest. In die tijd stoof mijn latere promoror, Harry Wesseling, enthousiast over de gangen van her laboratorium. In zijn handen een kopie van een baanbrekend artikel. Dat beschreef een medicament dat zeer goed werkre bij patiènten mer hartfalen.

Her bruiste op dat lab, en in her hele vak. Ook als student merk te je hoe dynamisch de cardiologie was. Sindsdien heb ik altijd her gevoel gehad onderdeel te zijn van een wereld die op het scherpst van de snede werkte en gremzen verlegde. Onderdeel te zijn wan een toonaangevende club.

Twintig jaar later, februari 2005, valt mij de eer te beurt on toe te mogen treden ror de Jonge Akademie van de KNAW. Jonge werenschappers wit alle vakgebieden zijn daarin bij elkaar gebracht. De eerste bijecnkomst was geweldig inspirerend, maar ook een 
eye-opener. Er was namelik hooguit én andere cardiovaculan gerichre onderzoeker te vinden. Dat terwij! er an het prettige gezelschap wan psychologen, neuro- en cognitiewetenschappers absolunt geen gebrek heerste. Plotseling voelde ik me weer met ats toen ik als 13-jarige met het Groningse Be Quick tegen de jeugd van Ajax mocht spelen. Tot die wedstrijd dacht ik echt bij een hele goede club te voetballen. We werden kansloos met 13-1 opgerold en in de bus gezet.

Die ervaring, ik bedoel die bij de KNAW, zerte mij ertoe kritisch naar mijn vak kijken. Zijn we ejgenlijk wel zo grensverleggend als ik al die jaren heb gedacht? Willen we dat wel? Of zijn we eigenlijk weinig geinteresseerd in fundamentele wetenschap? Worden we cen wak dat snel wil toepassen, uirproberen wat elders is bedache? lk vrees voor het laatste.

Ik vrees dar in ons vak de behandelingen, sneller groeien dan ons inzicht. Ik vrees dat met het enome succes van ons vak in de afgelopen jaren, we de biologie, de onderliggende basis wan ons vak, dreigen ve laten glippen..

Lk wil u vandaag laten zien dac we een tekort oplopen wan mensen die ons valk woorzien van basal begrip, van fundamentele biologie. Daarmee verdwijnt het fundament, de biologie uit onze op. leiding, en uit ons denken. Dat levert een worm van zorg, een vorm van technologie op die Lewis Thomas als duur en onafgemaak beschreef: geavanceerd mar tegelijk diep primitier. ledereen boven de viftig een cholesterolverlager en een aspirientje. ledereen na een groot hartinfarct een inwendige defibrillator. Het werkt vast, mar op basis van brute technologische kracht. Geavanceerd, duur, maar ook natef. Een uiting van een onvolledig begrip van de warkelike mechanismen. Vowardige technologic, gebasecrd op diep en volledig begrip, is eenvoudig en tegelijk verblutfend efficient. Antibiotica voor een longontsteking, Gleevec voor chronische leukemic. 
Onze drang nar technologie, naar nieuwe trucs stat ons vaak in de weg om volwardige technologie re creeren. Dr. Hamblin, hemaroloog, selveef in 2005 een artikel over leukemie. Zijn slotzin luide: "treament strategies based on the new biology are in development'. Latat dit even doordringen 'treament strategies based on the new biology are in dewelopment"

Ik zie in ons gebied te wakk 'rreatment strategies based on the new rechnology are in development. En dat is een wereld van verschil. Want het uitresten wan nieuwe rechnologie, simpelweg ondat die voorhanden is, based on new technology, is heel wat anders dan het formuleren van een nieuw concept, based on new biology. In het ecrste geval gat het om een nieuwe truc: een nieuw apparat, of en nieuw medicijn. Maar als je uicgaat van een nieuwe biologie, ga je uit van een nieuwe manier om tegen het oude probleen aan te kijken. Plotseling zie je de kerk als een feesttent.

We moeren niet met technologie beginnen, maar met biologie, met inzicht. Niwuwe biologie leunt op jong wetenschappelijk toptalcnt. Er bestaan echter weinig getallen over het talent in ons vak. We kennen gevestigde toppers als Patrick Serruys, Maarten Simoons en Frirs Rosendal, de best gecireerde Nederlandse cardiovasculaire onderzoekers. Maar de vragg is hoeveel nieuwe jonge Serruysjes, Simoontes en Rosendaalrjes we de komende jaren mogen verwachten.

Dat heb ik geprobeerd in te schatten door te kijken hoe ons wak het doet in wetenschappelijke competities. De jaarlijkse comperities warin onderzoeksgeld wordt verdeeld. Warbij vaak alleen 10-20\% van de beste platmen word gehonoreerd. In de jaarlijkse wedstriyd van de Hartstichting competeren de cardiovascullaire centra onderling dus dar geeft geen inziche. Een veel interessantere comperirie om naar te kjken is de zogeheten VENI-VIDI-VICI compertie die NWO elk jaar organiseert. Dit is een comperitie wall alle wakgebieden in meedoen, kamebreed, voor de beste 
10-15\%. In deze competive kan ons cardiowasculaire whent zich meten met de slimme jongens en meisjes uir de oncologie, newrowetenschappen en dergehijke. Het binnenhalen wn een subsidie in dexe caregorie is een belangrike erkenning van wetenschappelijke kwaliteir en ralent. Er zijn echer geen getallen die aungeven hoe wij het in deze comperitie doen. IK heb het daarom voor vandang cens op een rijte gezer.

De VENI-competitie is voor do pas gepromoveerde, VIDI voor de wat meer gevestigde onderzoeker en V'Cl voor de echte top. Beginnen we mer de VENI her minst zware deel, daar zin in total voor alle biomedische wetenschappen per jar ca. 35 platsen uit te delen. Van alle VENl's witgedeeld wanaf 2002 ging $32 \%$ nar cognitie-/neurowetenschappen. Cardiovasculair deelt met immunologie de rweede plats mer 19\%. Opvallend is dat de genetica met $14 \%$ op de vierde plats stat, oncologie op de vijlde plats met $11 \%$, longziektern onderan mer $5 \%$. Deze goede score van cardiovasculair houdr een mooie belofte in voor de roekomst.

De VIDI competitie is meteen forse stap omhoog. Hier zijn er jaarlijks maar 18 van beschikbaar en men moet al duidelijk bewezen hebben tot de top te horen. Hier is opneuw cognitie-en neurowerenschap de absolute winnar net $34 \%$, gevolgd door genetica. $23 \%$, dan immunologie $17 \%$, en oncologie met $13 \%$. Dararna pas komt cardiovasculair met $10 \%$. Dit is verbazend: war we het goed doen met het vroege talent, zijn we in her stadium verder mereen al degradatiekandidaat.

Tot slot, de top van de ranglijst, de VICI competitie: hier worden er maar zo'n 5 per jaar uirgedeeld, dus dat is een erg pirtige competitie en het gat om de absolute top. Mar het gatat dan ook om serieus geld: 1,25 miljoen euro. Dir soor subsidies versterk zichzelf. Door veel geld in én onderzoeksgroep te steken, wekt die groep hele goede nieuwe $A O^{\prime}$ 's an die op hun beurt in een rijke omgexing zich goed ontplowien en zolf darma weer ande 
VEN mee kunnen doem. Dit zijn ook bedragen die bijna drie keer zo hoog liggen als her maximum in de ronde wan de Nederlandse Hartstichning. Helaas, he blijkt dat $50 \%$, de helf van deze verpor, gaat maar, u raadi her al, de neuro-en cognitiewerenschappen. Er zijn in die jaren van de 20 VICl's maar 2 op cardiovasculair gebied gevallen.

Wij staan op onze symposia dure drankjes te drinken en stoer te tetreren over hoeveel dotters en pacemakers we deze week weer hebben gedaan, maar de jongens en meisjes in de neurowerenschap winnen gewoon met vlag en wimpel de titel, en nemen daarmee bezir van een belangrijk deel wan het onderzoeksbudget. Daardoor kunner zij meer talent voorbbrengen en hun vak beter innoveren. Daardoor sta ik op de KNAW veel met hersenonderzoekers te borrelen. Heel gezellig.

U vraagt zich af warom dit een probleem zou zijn. De cardiologie heef immers altijd veel onderzoeksgeld niet via NWO maat via de industrie werworven. Zoals dat artikel in handen van Harry Wesseling, dat betekende weel projecten rondom het nieuwe medicijn. Maar daar zic hem ook meteen de kneep. Industrie-gebonden onderzoeksgeld is heel wak gericht op de korte temijn. Op toepassing. Industriegeld makt van ons toepassers in plaats wan bedenkers. We drijwen darmee af van biologisch begrip.

Ik geef een voorbeeld hoe de biologie, en de dagelijkse praktijk wit elkar dreigen re lopen. Onze groep doet onderzoek naar hartfalen. Hertalen is een verzameherm voor kachten die ontstan als de hartspier niet goed meer werkt. De huidige klinische definirie stant uit 1930. Vemand heef hartalen als er typische klachten zijn, en tegenwoordig willen we liefst ook enig teken van een gestoorde hartunctic erbij zien, man in sommige klineken hoef dat nuet. Klachten en een reactie op behandeling is voldoende om deze diagnose re stellen. Alsof een bobbeltje in de nek genoeg is on te zeggen dar lemand ex kwadardig gezwel heeft. 
Het is naser verwonderlijk dat de huidige wetenschappelike definitie van harfalen gederailleerder is geworden. Als wij op een congres willen laten zien dat er in een experiment sprake van hartalen is, moeten we de moleculaire veranderingen laten zien die bij hartfalen horen. De meer biologische, principiële definicie wan hartfalen leunt op meting van BNP. BNP, ik zal u de afkorting besparen, is een zeer bijzonder molecuul. Hartspiercellen maken BNP alleen als reactie op een te $z$ ware belasting. Dat is dus cen ideal verklikker molecuul, want als de hartspiercel BNP makt is er war loos. BNP is eenwoudig in her bloed te meten. Op congressen warr biologen over hartfalen praten is het dus al jaren zo dat ik verhoging van BNP moer laren zien om in een model harrfalen aan te tonen. Ondercussen kan $i k$ bij patiënten alleen al op basis wan klachten de diagnose harfalen stellen. We hebben veel onderzoek gedaan naar de meting van BNP bij mensen die worden verdacht harrfalen te hebben, volgende week promoveert Roland van Kimmenade daarop. En ik kan u verzekeren, als het BNP niet verhoogd is, is het geen hartalen. We kunnen harfalen wat mij betreft dan ook anders definiëren. Het kan alleen hartfalen zijn als ook het BNP verhoogd is. Daarmee is de diagnose voorzien van een biologisch goed re begrijpen gouden standaard.

Naast BNP hebben we een nieuwe verklikker ontdekt. Een stof die ongunstige moleculaire veranderingen in thet hart verraad. Neem twee mensen mer te hoge bloeddruk. Bij beiden maak ik een echo van het hart en daarop is te zien dat de hartspier door de hoge bloeddruk te dik is geworden. Ogenschijnlijk hebben ze dus hetzelfde probleem, en ik heb volgens de huidige normen een adequate inschatting gemaakt. Toch geef ik u op een bricfje, die twee hartspieren zijn niet gelijk. In de ene harrspier kunnen ondertussen zeer ellendige cellen hard aan het werk zijn die hartspier te verslechteren, zonder dat ik het in de gaten heb. Dat inzicht heb. ben we gekregen toen we hebben gevonden dat in cen hartspier die 
dreigre gan falen, dic dus pas larer slechter wordr, al in een wroeg stadium buirengewoon nate cellen actief worden. Cellen die de stof galectine-3 maken, wat gen pretrige substancie blikt te zin. We hebben dat galecrime-3 rwee jaar geleden ondekt wia onderzock met DNA chips, wamer we 30.000 moleculen tegelijk konden screenen. Nu, is samen met professor Marja van Dieijen, van onze Kinische chemie, dazelde galectine-3 al bij meer dan 1000 patienten gemeen. Die metingen laten zien dat een werhoogd galectine-3 in hat bloed, voorspelt of een parient een ernstig beloop zal hebben, gegevens warvan ween deel binnenkort publiceren. Ik wind het fascinerend om te bedenken dat galectine-3 in 2003 als nietig vekje oplichte op een DNA-chip, in de handen van Rudy Duisters, Rick van Leeuwen en de andere tigers van ons lab, en dat het nu wellichteen kJinisch toepasbare test kan worden.

We zien wooral dat de combinatie van cen verhoogd BNP met cen verhoogd galectine 3 erg ongunstig is. Dir betekent dar een combinatie van moleculaire markers, een panel in her bloed te meten scoffen gezamenlijk een vrij nauwkeurig beeld geef wan werschillende cellen in de hartspier. Daarmee waarderen we dar twee harspieren warvan we nu nog denken dat die herzelfo probleem hebben, eigenlijk sterk verschillen, ook en met name in uitkonst.

Dit onderzoek is mogelijk gemaakt door geld wan NWO en van de Hartstichting. En door een zeer intense samenwerking met de cardiologie in het $A M C$, warin we samen fundamentele vagen kunnen stellem. Terwijl het aanvankelijk niet ging om een klinische toepassing, lijkt die er toch te komen. Dac is toeval, mar dat roeval is denk ik een handje geholpen door de mogelijk heid heel fundanenteel te beginnen. Misschien wel atgedwongen, zoals bij lucky Ajax. Dat het slechtste seizoen in derrig jatr toch met een groor foest geheel in stijl afsluit inclusief bijbehorende rellen. $1 \mathrm{k}$ kan u zeggen dat de stemming bij mijn oudsce erook ardig van is opgeknape. 
Zoals Thomas het beschreef is onafgemaake, onvolgroctute technologie te wijten aan een gebrek aan inzichr. De enige manter om naar volwaardige technologie te komen is via neuwe kemis. En de enige denkbare bron van nieuwe kennis is onderzoek. Basal en weinig toegepast. Die gedache is al veel vaker geuir, maar een probleem is dat we te weinig nieuw ralent genereren. Ondanks incidentele successen trekken we te weinig onderzoeks-euro's aan. Daarbij komt dat elke moeizaam bevochten euro ook verdeeld raakt over een groot aantal instellingen.

De oplossing ligr voor de hand maar vereist veel. Het vergt vooral het vermogen om, soms over de eigen lokale belangen heen, een groot geheel te creëren. Nederland heeft een mationaal onderzoeksinstituut nodig op her gebied van hart- en vaatziekten. Een instiruut dat vanaf de basis verder aan ons vak kan bouwen. Dat mensen en middelen bundelt en daamee een voedingsbodem is voor talent. Dergelijke instituten bestaan in ons land al langer op het gebied wan de oncologie, de cognitiewetenschappen, op veel meer terreinen. Bijna allemaal behoren ze tot de wereldop. Er is geen enkele reden warom een narional instituut op het gebied. van hart-en vaatziekten minder succeswol zou zijn. Er zijn al goede en zeer vruchtbare relaties tussen de verschillende centra en mer de Hartstichting. Het ICIN speelt daarin een belangrijke fol, en verschillende centra hebben ieder op eigen terrein enorme experrise opgebouwd. We moeten de komende jaren het laatstezetje geven om te komen tor een herkenbaar nationaal instituut voor hart- en vaatziekten.

In lijn hiermee is binnen her ICIN een begin gemaakt met nationale onderzoksfaciliciten, warin ICIN en de KNAW investeren om de biologische benadering wan ons wak te versterken. Bijwoorbeeld door middel van een landelijke instelling voor het onderzock naar erfelijke factoren bij hartalandoeningen, die samen met Wouter Jukema ingericht zal worden. Wouter, ik kijk er naar wic om dat 
samen te down. Dat gart borrelen, dat is zeker.

Een woede en nog ved groter plan is om een institutu voor moleculare genessikude in te richten warin naast unversitaite groepen ook o.a. Philips participeert. Dan gaat het over investeringen van vele miljoenen. De eerste annzet is al gegewen. Er is reeds een onderzoeksprogramma gestart waar nast het academisch Ziekenhuis en de Universireit van Maastricht, ook Philips en de TU Eirdhowen gezamenlijk investeren. Nier alleen in plannen mat ook in intrastructuur. Mer als doel onze biologische kennis te verdiepen, richting moleculaire geneskunde. Om veranderingen op noleculair niveau te meten. Bijwoorbeeld ons eerder genoemde panel samen met andere nieuwe verklikkers. Een dergelijk panel vormt een soort wan moleculaire A.PK keuring om regelmatig bij hoog risico patiënten, zoals diabeten, te doen. Dan kumnen subtiele moleculaire warschuwingen laten zien dat or onheil nadert.

Tot slot. Dat ilk hier wandaag sta, is re danken aan familie, vrienden en collegae dic allen op hum eigen manier beslissende zijn geweest. Het zijn er velen, maar gezien de beperkte tijd kan $i k$ mar enkelen noemen.

Uk wil beginnen het ICIN re danken, met name de directenren Wiek van Gilst en Ces Visser danken voor de wijhheid warmee ze het ICIN besturen en voor het vertrouwen dat ze in mij hebben gesteld. Ook de KNAW wil ik bedanken woor deze benoeming, en voor het instellen van de Jonge Akademie, wat voor mij een enorm inspirerende plek is geworden.

Mijn benoeming is mogelijk gemaakr door her college van Bestum van de Unwersiteit Maastricht en de Raad van Bestur van het academisch Ziekenhuis Maastricht. llk dank ze dan ook woor de mogelijkbeden die ze mij bieden en het vertrouwen dat ze in mij hebben 
gesteld. Voorzitter van her college van besuur, Jo kitzen en rector magnificus Gerard Mols hebben beiden op beslissende momenten geweldig veel steun gegeven, watwoor mijn oprechre dank. Op minder spannende momenten hebben we de wereldproblematiek bij een fles wijn als sneeuw voor de zon laten verdwijnen, war minstens zo zeer gewaardeerd wordr. Ik dank evenzeer onze decaan, Harry Hillen, die in hoge mate aan deze benoening heef bijgedragen. Ik ben ook veel dank verschuldigd aan onze voorzitter van de raad van bestuur, Guy Peeters, die sinds zijn komst met tomeloze energie ons ziekenhuis vernieuwt en innoveert, wat ook een belangrijke drijfveer is achter de vorming van ons hart-vaatcentrum in Maastrichr. Ik wil ook mijn dank uiren ann het Universiteits Fonds Limburg voor mijn benoeming op de Dr. Tansleerstoel.

Ik wil mijn opleiders, Henk Lie, Jo May, Dirk-jan van Veldhuisen en de anderen op de afdeling Cardiologie in Groningen bedanken woor de geweldige tijd die ze mij daar hebben gegeven. Henk is altijd de vaderlijke opleider gebleven die me ook nu nog regelmarig met advies bijstaat.

In juli $2001 \mathrm{kwam}$ ik uir Groningen in Maastricht, achter Harry Crijns aan die daar toen net was begonnen als afdelingshoofd. $1 \mathrm{k}$ heb me in het begin wel eens afgevraagd of ik er wel goed aan had gedaan, en de staf misschien ook wel, maar zijn niet aflatende steun, samen met de steun wan mijn collega's hebben erwoor gezorgd dat ik me geweldig op mijn plek ben gaan voelen. Ik wil ook Harry Struijker-Boudier danken die als directeur van CARM bijna ongemerkt voor de broodnodige wind in de zeilen kan zorgen.

Ik wil met zeer grote nadruk mijn lab, de experimentele en moleculaire cardiologie danken. Rick van Leeuwer is de hoofdanalist en strijder van het eerste uur. Vaak staan we ever in de gang en denken terugaan het prille begin, toen we 4 jaar geteden met zijn 
dreen begonnen. Wu is het een plek wat het alrid bruist en wat dk nickw idee, elke nieuwe techmick binnen twee manden uit te woren walt. Ih woel dara clke dag hoe geweldig her is om werenschap te mogen bedripen. Dat is te danken aan de geweldige vermogens van Stephawe Heymans, Rick van Leewwer, Rudy Duisters, Blanche Schroen, Mark Schellings, Joost Leenders. Nard Kubben, Geen van Almen, Melissa Swinnen, Mirjam van Loom en Jop van Berlo. Aan de klnische kant is Roland wan Kirmenade mu klatar. Nu trek Luc Eurlings samen met het cluster hartalen en daarmee ook alle onderzockers in Nederland de PRIMA studie die dankzij hun formidabelle inspanning nu fraxi op de rails staat.

Dir, alles, en wooral ook ondergetekende, wordt bij elkargehouden door Bianca Bastings, mijn secretaresse; ook vandaag onmisbaax. Zonder haar had minn roga waarchijnlijk nog ergens in Mastricht gehangen. Dank ook aan Emmy, Jacqueline, Mariame woor hun steun.

lk ben enorm blij en trots dar ik met mijn ouders deze dag samen kan beleven. Wat er ook gebeurde, jullie kozen onmiddellijk en zonder ook mar wen enkele vraga te stellen alrijd onze kant. Een ramp voor leraren, en voor de enkele politicagent die zo eens langs kwam. Dat je ouders altijd zo wolstreke vanzelfsprekend in je geloven leverc een heerlijk gevoel op, en ik hoop dat ik her ook zo goed mag doen. Ik ben verzot op mijn kleine broertjes Yair en Matamja en mijn zusje Chedwa, ook al doen ze lang niet altijd meer wat ik zeg. Mijn schoonouders, Hans en Henriette, staan altijd mer rad en daad klar en, na elke moeilike beslissing zeggen ze weer dat het echt de beste is die we konden nemen.

Toen ik net een parmanden uit Amerika terug was zorgde mijn zus Chedwa wrwoor dat it Sara-Joan tegen her welgeschapen lij liep. Dat ze ook nog een hoop hersens meenam lexk mij voor te- 
mand die er zo urzag vrij overbodig. Lieve. lieve Sama-jan, we hebben recent weer eans gezien hoe moeiljk her kan zijn om twee carrieres op elkar af te stemmen. Dat krijg ie met die hersens. Het belangrijkste is dat we echt alles samen beleven. Je bent mijn matje en ik genier elke dag van je onvoorwardelike lietde.

Lieve Aylon, Soesja en Elya. Ik noem jullie drieenn als lantse. Je moet weten: mijn laatste woond in deze kerk is bewand woor her aller-, allerbelangrijkste deel van dir verhal. En her belangrijkste, dat zijn jullie. Elke keer dat ik mer jullie in een kerk mag zirten, is het een feestrent.

Ik heb gezegd. 


\section{Referenties:}

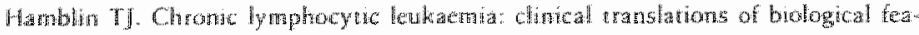

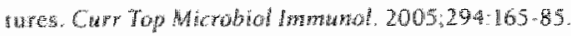

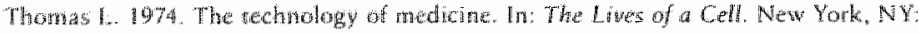
Whimgress; $1974: 31-36$

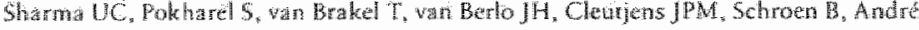

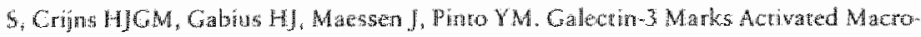

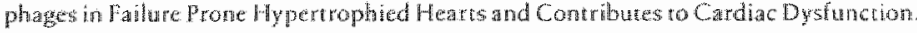
Cincutarion $2004,110,3121-8$.

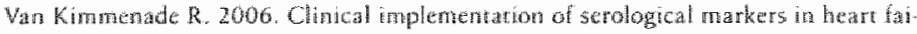

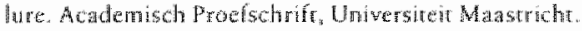

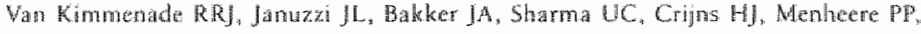

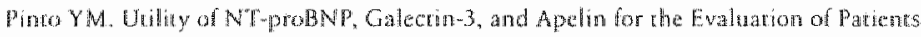

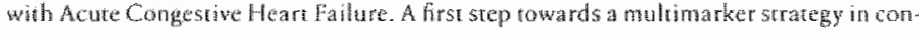

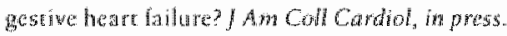


